\title{
Sustainable Concrete with Rice Husk Ash (RHA) for Marine Structures
}

\author{
Francisco A. Martinez Urtecho ${ }^{1}$, Luis J. Oyanguren Gallo ${ }^{1, a}$, José U. Rodriguez Barboza ${ }^{1}$, Elsa Carrera Cabrera ${ }^{1}$ \\ ${ }^{1}$ Ingeniería Civil, Universidad Peruana de Ciencias Aplicadas, Lima, Perú
}

\begin{abstract}
In recent years, attention has focused on addressing the environmental problems caused by the use of construction materials, proposing to develop new environmentally friendly concrete; One of the alternatives that has emerged is to replace cement or aggregates with agricultural waste because its treatment is expensive and not very sustainable; This is the case of rice husk ash (RHA), the main agricultural residue resulting from this cereal, which represents an abundant production worldwide. Marine reinforced concrete structures are in constant exposure to the marine environment, so that their structural capacity and useful life are affected by the breakdown of aggregates, which cause a greater amount of free $\mathrm{CaO}$ and $\mathrm{MgO}$ in concrete mixtures, and the penetration of chloride ions, which destroy the passive layer of steel and produce cracks in the concrete that cause loss of load and structural damage. In this investigation, cylindrical specimens of conventional concrete and sustainable concrete with cement replacement percentages of $5 \%, 10 \%$ and $15 \%$ RHA have been developed. The results show that for a $5 \%$ RHA replacement, the compressive strength is greater than conventional concrete at an early age; the disintegration of the aggregates decreases, being for the fine of $9.86 \%$ and for the coarse aggregate of $4.34 \%$, the penetrability of sulfate ions decreases as the percentage of RHA replacement increases, the permeability of conventional concrete is much greater with respect to RHA replacement concrete and, finally, the unit cost analysis per cubic meter of RHA concrete is less than conventional concrete
\end{abstract}

\section{Introduction}

In recent years, environmental problems caused by the use of construction materials have been the focus of attention worldwide, with one of the most polluting being excessive cement production; According to [1] cement production has a carbon footprint of 0.8 Ton of $\mathrm{CO}_{2}$; For this reason, the use of agricultural resources is being introduced as a replacement for materials since such wastes are not very sustainable and expensive when doing some treatment. One of the most important residues is the rice husk, which forms the outer covering of the grain of this cereal and is always removed during the milling process [2], the rice husk constitutes $20 \%$ of the volume of rice produced annually, which borders the 80 million tons [3]. Rice husk ash (RHA) is obtained from the burning of the husk, where its evaporable components are lost during burning leaving silicates as waste; The amount of silicates is a function of the burn time and the combustion temperature. RHA is a fine material with a particle size generally less than $45 \mu \mathrm{m}$ and an average particle size of $610 \mu \mathrm{m}$. This has similar characteristics to cement, starting with the high silica content, making it suitable for use as an addition; however, the combustion temperature range and burn time must be considered [4].

Marine reinforced concrete structures such as marine walls, breakwaters and cladding, coastal docks, bridge and underwater emissaries are exposed to the marine

\footnotetext{
${ }^{\mathrm{a}}$ Corresponding author: u201417614@upc.edu.pe
}

environment. Underwater emissaries, according to Smith [5], are used to transport seawater, bulk products, oil and gas and effluents, and are generally manufactured from steel or high density polyethylene (HDPE); Likewise, the author tells us that concrete is used to give weight to the pipe and thus give it sufficient stability under the load of waves and ocean currents [5].

The maintenance of marine structures in China, ports and docks, for 2014, presented a cost of 0.19 billion RMB equivalent to more than 114 billion euros [6].

Underwater emissaries are exposed to the formation of a gel that is caused by the reactivity of the alkalis of the siliceous aggregates, which have an alkali-silica reactivity (ASR); This gel is harmless by itself; The problem is its ability to absorb water because it expands in the presence of moisture causing a pressure that leads to the formation of excessive cracks in the concrete thus reducing its structural strength [7].

It's affirmed that the aggregates to be used in reinforced concrete exposed to seawater must have a good performance and durability in the structures, so it must be essential the tests of disintegration of aggregates either by sodium or magnesium sulfate [8].

It's mentioned that the disintegration results for mixtures incorporating RHA decrease; For example, the mortar paste has a disintegration of $1.3 \mathrm{~mm}$; After replacing $40 \%$ of the cement with RHA, the disintegration is $0.8 \mathrm{~mm}$. The decrease in aggregate disintegration can be attributed 
to a lower amount of free $\mathrm{CaO}$ and $\mathrm{MgO}$ for mixtures with RHA [9].

On the other hand, chloride ions are responsible for destroying the passive layer of steel reinforcements, which is called de-passivation, this causes cracks in the reinforced concrete structure that reduce the loss of charge and cause structural damage [10].

It's also stated that chlorides in concrete structures exposed to the marine environment can penetrate through the concrete deck to induce corrosion of reinforcing steel and thus deteriorate reinforced concrete structures; So the understanding of the mechanism of transport of chlorides in concrete is essential for the prediction of the useful life of reinforced concrete structures [11].

Additionally, resistance to chloride ion penetration tends to improve over time, since cement hydration reactions further reduce the porosity and connectivity of concrete pores [12].

Although the greater porosity contributes to a greater initial penetration of chloride ions, studies have shown that the difference in yield is compensated over time [13]

The city of Chimbote in Peru presents submarine emissaries that are protected with ballast of reinforced concrete, which don't have an acceptable durability due to their detachment, which causes accidents to artisanal fishing vessels; Therefore, the study is aimed at the development of concrete with partial replacement of RHA.

In this regard, [14] use $5 \%, 15 \%$ and $25 \%$ of RHA as a replacement in an Ordinary Portland Cement (OPC), resulting in all of its concrete samples exceeding the design strength after 28 days of curing ( $20 \mathrm{MPa}$ ), although none exceeds the concrete strength of the standard concrete. Likewise, [15] finds in its investigation a high early resistance of concrete with the addition of rice husk ash with respect to the standard concrete which demonstrates the rapid reaction of the ash hydration mechanism. They also state that using 20\%, $30 \%$ and $40 \%$ of rice husk ash from the crust (GRHBA), chloride ion penetration is decreased by increasing the replacement percentage for a longer cure time.

In the present investigation the percentage of cement replacement of $5 \%, 10 \%, 15 \%$ of RHA in the standard concrete is studied, studying the breakdown of coarse and fine aggregate, the cost of concrete with RHA; as well as the influence of $5 \%, 10 \%$ and $15 \%$ of RHA on the rapid penetration by chloride ions, the resistance to compression and the depth of penetration of water under pressure.

\section{Materials and methods}

\subsection{Materials}

Portland cement type V has been used because it is best suited to counteract the damages caused by sulfates present in marine environments.

As a fine aggregate, coarse sand from the "La Sopresita" quarry was used in Chimbote with a specific weight of $2.63 \mathrm{~kg} / \mathrm{m}^{3}$, modulus of fineness of 3.29 and $0.99 \%$ absorption.
The gravel with a diameter of 1" that was used as a coarse aggregate was obtained from the "La Sopresita" quarry in Chimbote, with a specific weight of $2.81 \mathrm{~kg} / \mathrm{m}^{3}$, and has a fineness module of 7.89 and $0.83 \%$ absorption.

The water used is potable from Sedachimbote S.A

Rice husk ash (RHA) comes from the department of La Libertad, its composition is shown in Table 1, and its characteristics in Figure 1. This component was used to replace type $\mathrm{V}$ cement in 5,10 and $15 \%$ within the concrete mix in order to study its pozzolanic reactivity.

Table 1. Composition of rice husk ash (RHA).

\begin{tabular}{|c|c|}
\hline \multicolumn{2}{|c|}{ RHA composition } \\
\hline Substance & Percent (\%) \\
\hline Silica & 86.98 \\
\hline Alumina & 0.84 \\
\hline Iron oxide & 0.73 \\
\hline Calcium oxide & 1.40 \\
\hline Magnesium oxide & 0.57 \\
\hline Sodium Oxide & 0.11 \\
\hline Potassium Oxide & 2.46 \\
\hline Sulfur Oxide & 0.24 \\
\hline Loss by ignition & 5.14 \\
\hline
\end{tabular}

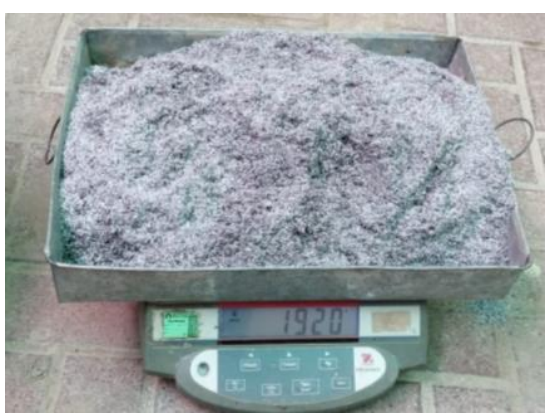

Figure 1. Rice husk ash (RHA).

\subsection{Desing mix}

The mix design that contains Type $\mathrm{V}$ cement will be called "standard mix design" since marine structures use this type of cement because of the damages caused by sulfates. The mix design was carried out using the ACI method [16] considering its recommendations on the required average strength, maximum nominal aggregate size, water-cement ratio, among others. Concrete mixtures with RHA have been made by replacing the amount of cement with 5\%, 10\% and 15\% RHA. 
Table 2. Mixing dosage.

\begin{tabular}{|c|c|c|c|c|}
\hline Materials & $\begin{array}{c}\text { Pattern } \\
\text { (RHA-0) }\end{array}$ & $\begin{array}{c}\text { RHA- } \\
\mathbf{5}\end{array}$ & $\begin{array}{c}\text { RHA- } \\
\mathbf{1 0}\end{array}$ & $\begin{array}{c}\text { RHA- } \\
\mathbf{1 5}\end{array}$ \\
\hline Cement (kg) & 13.39 & 12.75 & 12.11 & 11.47 \\
\hline RHA (kg) & - & 0.64 & 1.28 & 1.92 \\
\hline Water (litros) & 8.19 & 8.19 & 8.19 & 8.19 \\
\hline Fine Aggregate (kg) & 23.58 & 23.58 & 23.58 & 23.58 \\
\hline Coarse Aggreagate (kg) & 25.15 & 25.15 & 25.15 & 25.15 \\
\hline
\end{tabular}

\subsection{Test}

Table 3. Test summary.

\begin{tabular}{|c|c|c|}
\hline Test & $\begin{array}{c}\text { Rice Husk } \\
\text { Ash (\%) }\end{array}$ & Norm \\
\hline Compressive strength & $0,5,10$ y 15 & NTP 339.034 \\
\hline $\begin{array}{c}\text { Rapid Penetration Test by } \\
\text { chloride ions }\end{array}$ & $0,5,10$ y 15 & ASTM C 1202 \\
\hline $\begin{array}{c}\text { Water permeability test } \\
\text { under pressure }\end{array}$ & 5,10 y 15 & $\begin{array}{c}\text { UNE-EN-12390- } \\
8\end{array}$ \\
\hline
\end{tabular}

This work has been developed in the Concrete Technology Laboratory of the UPC-HUB San Miguel and in the laboratories of GEOMG S.A.C. and UNICON; and the tests performed are shown in Table 3, Table 4 and Figure 2. The aggregate disintegration test, the characteristics of the specimens, as well as their test ages are shown in Table 4, Table 5 and Table 6.

Table 4. Details of test specimens

\begin{tabular}{|c|c|c|c|c|}
\hline \multirow[b]{2}{*}{ Test } & \multirow[b]{2}{*}{ Code } & \multirow{2}{*}{$\begin{array}{c}\text { Trial Age } \\
\text { (days) }\end{array}$} & \multicolumn{2}{|c|}{ Concrete Specimens } \\
\hline & & & $\begin{array}{c}\text { No. of } \\
\text { samples }\end{array}$ & $\begin{array}{l}\text { Dimensions } \\
\text { (cm) }\end{array}$ \\
\hline \multirow{4}{*}{$\begin{array}{l}\text { Compressive } \\
\text { strength }\end{array}$} & RHA-0 & $7,14,28$ & 3 & $15 \times 30$ \\
\hline & RHA-5 & $7,14,28$ & 3 & $15 \times 30$ \\
\hline & RHA-10 & $7,14,28$ & 3 & $15 \times 30$ \\
\hline & RHA-15 & $7,14,28$ & 3 & $15 \times 30$ \\
\hline \multirow{4}{*}{$\begin{array}{l}\text { Rapid } \\
\text { Penetration Test } \\
\text { by chloride ions }\end{array}$} & RHA-0 & 28 & 3 & $15 \times 30$ \\
\hline & RHA-5 & 28 & 3 & $15 \times 30$ \\
\hline & RHA-10 & 28 & 3 & $15 \times 30$ \\
\hline & RHA-15 & 28 & 3 & $15 \times 30$ \\
\hline \multirow{4}{*}{$\begin{array}{l}\text { Water } \\
\text { permeability } \\
\text { test under } \\
\text { pressure }\end{array}$} & RHA-0 & 28 & 1 & $15 \times 30$ \\
\hline & RHA-5 & 28 & 1 & $15 \times 30$ \\
\hline & RHA-10 & 28 & 1 & $15 \times 30$ \\
\hline & RHA-15 & 28 & 1 & $15 \times 31$ \\
\hline
\end{tabular}

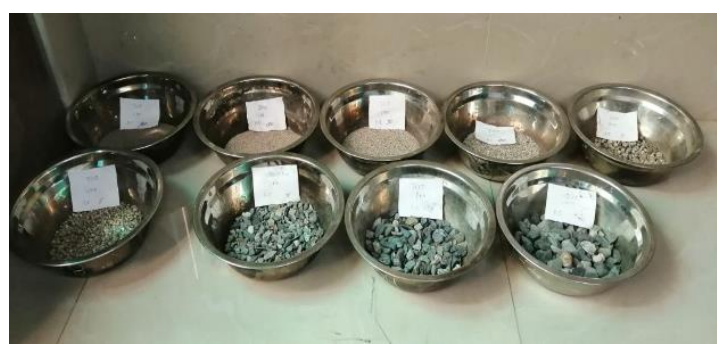

Figure 2. Samples submerged in Magnesium Sulfate.

\section{Results}

\subsection{Soundness of fine and coarse aggregates in Magnesium Sulfate}

Table 5 and Table 6 show the influence of the disintegration of aggregates according to ASTM C88 [17]. The results indicate that for the coarse aggregate, in the $1 / 2$ "sieve there is a loss of $4.77 \%$, for the $3 / 8$ " sieve the loss is $11.51 \%$ and, finally, for sieve No. 4 , it is lost $3.70 \%$ Applying the correction factor given by the mentioned Standard, a total corrected loss of $4.34 \%$ is obtained, being a favorable aggregate for the design of concrete.

On the other hand, the results for the fine aggregate, sieve No. 8 presents a loss of $8.50 \%$, for No. $16,7.90 \%$ is lost, likewise, for No. 30 a loss of 19.70 is observed, and Finally, for sieve No. 50, 3.70\% is lost. Likewise, applying the correction factor obtains a corrected loss of $9.86 \%$, being a favorable aggregate for the design of concrete.

Table 5. Quantitative analysis of coarse aggregate.

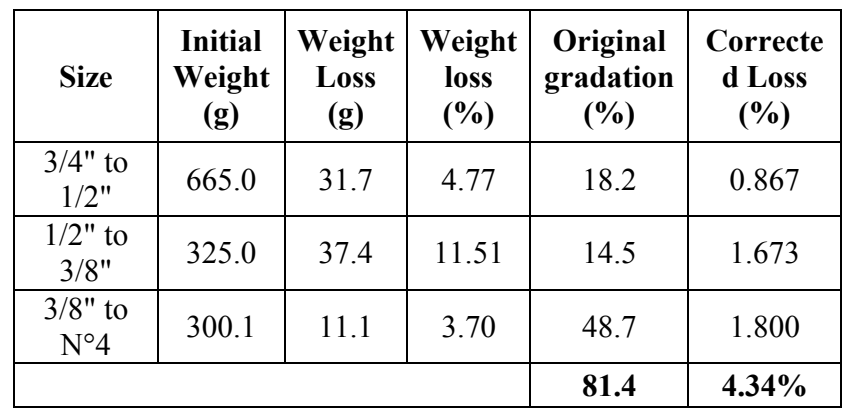

Table 6. Quantitative analysis of fine aggregate.

\begin{tabular}{|c|c|c|c|c|c|}
\hline Tamaño & $\begin{array}{c}\text { Initial } \\
\text { Weight } \\
\text { (g) }\end{array}$ & $\begin{array}{c}\text { Weight } \\
\text { Loss } \\
(\mathbf{g})\end{array}$ & $\begin{array}{c}\text { Weight } \\
\text { loss } \\
(\%)\end{array}$ & $\begin{array}{c}\text { Original } \\
\text { gradation } \\
(\%)\end{array}$ & $\begin{array}{c}\text { Corrected } \\
\text { Loss (\%) }\end{array}$ \\
\hline $\begin{array}{c}\mathrm{N}^{\circ} 4 \text { to } \\
\mathrm{N}^{\circ} 8\end{array}$ & 100.0 & 91.5 & 8.50 & 19.6 & 1.670 \\
\hline $\begin{array}{c}\mathrm{N}^{\circ} 8 \text { to } \\
\mathrm{N}^{\circ} 16\end{array}$ & 100.0 & 92.1 & 7.90 & 24.7 & 1.955 \\
\hline $\begin{array}{c}\mathrm{N}^{\circ} 16 \text { to } \\
\mathrm{N}^{\circ} 30\end{array}$ & 100.0 & 80.3 & 19.70 & 18.0 & 3.549 \\
\hline $\begin{array}{c}\mathrm{N}^{\circ} 30 \text { to } \\
\mathrm{N}^{\circ} 50\end{array}$ & 100.0 & 79.1 & 20.90 & 12.8 & 2.681 \\
\hline \multicolumn{7}{|r}{} & & $\mathbf{7 5 . 2}$ & $\mathbf{9 . 8 6 \%}$ \\
\hline
\end{tabular}




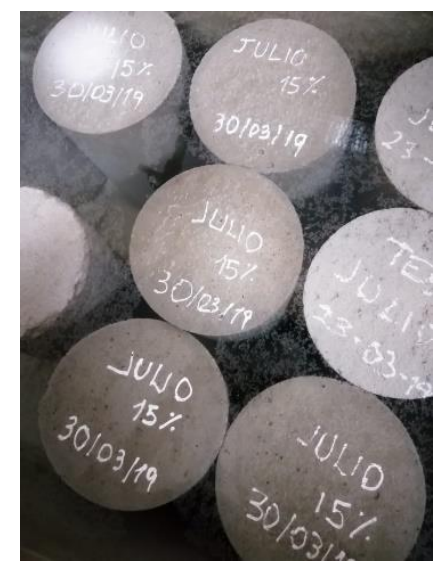

Figure 3. Hardened specimens in curing stage (Source: Own elaboration).

\subsection{Compressive strength}

Figure 4 shows the incidence of the percentage of RHA on compression resistance for different test ages according to ASTM C39 [18].

According to the results, considering conventional concrete as a standard concrete, it can be stated that the compressive strength increases as the percentage of RHA increases from $0 \%$ (standard concrete) to $5 \%$ and from there it decreases to the value of $15 \%$. The maximum resistance value reached at 28 days is $316.13 \mathrm{~kg} / \mathrm{cm}^{2}$ and represents a $3.2 \%$ increase with respect to the standard concrete and the minimum value of $49.48 \mathrm{~kg} / \mathrm{cm}^{2}$ representing a $16.2 \%$ decrease with respect to the standard concrete.

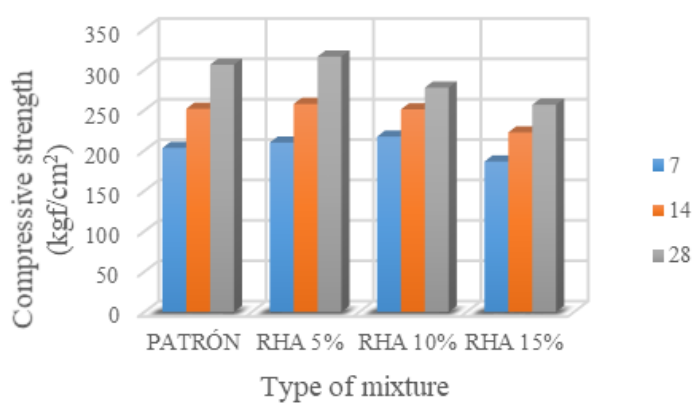

Figure 4. Summary of results of the compressive strength of all types of concrete at 7, 14 and 28 days of curing.

\subsection{Rapid penetration by chloride lons}

Also, Table 7 shows the summary table of the rapid penetration test for chloride ions in all samples of hardened concrete according to ASTM C1202 [19]; both in conventional concrete and in cement replacements with the percentages of rice husk ash. The control or conventional concrete has a high and moderate classification of chloride ion penetrability, in contrast, the concrete with the highest percentage of RHA studied, has a low and very low classification, having a difference of up to 3082 Coulomb that have penetrated $(75.9 \%$ difference) in the most critical case.
Table 7. Chloride ion rapid penetration test result.

\begin{tabular}{|c|c|c|c|c|}
\hline Sample & a/c ratio & $\begin{array}{c}\% \\
\text { RHA }\end{array}$ & $\begin{array}{c}\text { Result } \\
\text { (Coulomb) }\end{array}$ & $\begin{array}{c}\text { Penetrability } \\
\text { (ASTM } \\
\text { C1202) }\end{array}$ \\
\hline RHA-0 & \multirow{3}{*}{0.45} & \multirow{3}{*}{ - } & 4059 & High \\
\hline RHA-0 & & & 3982 & Moderate \\
\hline RHA-0 & & & 3520 & Moderate \\
\hline RHA-5 & \multirow{3}{*}{0.45} & \multirow{3}{*}{5} & 2537 & Moderate \\
\hline RHA-5 & & & 1783 & Low \\
\hline RHA-5 & & & 1436 & Low \\
\hline RHA-10 & \multirow{3}{*}{0.45} & \multirow{3}{*}{10} & 1625 & Low \\
\hline RHA-10 & & & 1542 & Low \\
\hline RHA-10 & & & 1835 & Low \\
\hline RHA-15 & \multirow{3}{*}{0.45} & \multirow{3}{*}{15} & 1381 & Low \\
\hline RHA-15 & & & 1139 & Low \\
\hline RHA-15 & & & 977 & Very low \\
\hline
\end{tabular}

\subsection{Water penetration depth under pressure}

Similarly, in Table 8 shows the summary table of the permeability test of hardened concrete under water pressure at the age of 28 days of curing. It is observed that the lowest penetration depth was $35 \mathrm{~mm}$ of concrete with $15 \%$ RHA replacement and represents a $47.8 \%$ decrease with respect to the standard concrete.

Table 8. Water Permeability test result in Hardened Concrete

\begin{tabular}{|c|c|c|}
\hline Sample & Age (days) & $\begin{array}{c}\text { Maximum Penetration } \\
\text { Depth (mm) }\end{array}$ \\
\hline RHA-0 & 28 & 67 \\
\hline RHA-5 & 28 & 55 \\
\hline RHA-10 & 28 & 49 \\
\hline RHA-15 & 28 & 35 \\
\hline
\end{tabular}

\subsection{Cost evaluation}

Table 9. Summary of cost per $\mathrm{m}^{3}$ of conventional or standard concrete.

\begin{tabular}{|c|c|r|r|r|}
\hline \multicolumn{5}{|c|}{ Conventional Concrete } \\
\hline Description & Unit & Quantity & \multicolumn{1}{c|}{ Unit cost } & \multicolumn{1}{c|}{ Partial } \\
\hline Fine A. & $\mathrm{m}^{3}$ & 0.6 & $\mathrm{~S} / 42.37$ & $\mathrm{~S} / 25.42$ \\
\hline Coarse A. & $\mathrm{m}^{3}$ & 0.73 & $\mathrm{~S} / 54.15$ & $\mathrm{~S} / 39.53$ \\
\hline Cement V & $\mathrm{m}^{3}$ & 9 & $\mathrm{~S} / 23.05$ & $\mathrm{~S} / 207.45$ \\
\hline Water & $\mathrm{m}^{3}$ & 0.172 & $\mathrm{~S} / 10.00$ & $\mathrm{~S} / 1.72$ \\
\hline \multicolumn{7}{|r}{} & $\mathrm{S} / \mathbf{2 7 4 . 1 2}$ \\
\hline
\end{tabular}


Table 10. Summary of cost per $\mathrm{m}^{3}$ of concrete added with $5 \%$ RHA.

\begin{tabular}{|c|c|r|r|r|}
\hline \multicolumn{5}{|c|}{ Concrete with 5\% RHA Replacement } \\
\hline Description & Unit & Quantity & \multicolumn{1}{c|}{ Unit cost } & \multicolumn{1}{c|}{ Partial } \\
\hline Fine A. & $\mathrm{m}^{3}$ & 0.6 & $\mathrm{~S} / 42.37$ & $\mathrm{~S} / 25.42$ \\
\hline Coarse A. & $\mathrm{m}^{3}$ & 0.73 & $\mathrm{~S} / 54.15$ & $\mathrm{~S} / 39.53$ \\
\hline Cement V & $\mathrm{m}^{3}$ & 8.55 & $\mathrm{~S} / 23.05$ & $\mathrm{~S} / 197.08$ \\
\hline RHA & $\mathrm{Bls}$ & 0.45 & $\mathrm{~S} / 5.00$ & $\mathrm{~S} / 2.25$ \\
\hline Water & $\mathrm{m}^{3}$ & 0.172 & $\mathrm{~S} / 10.00$ & $\mathrm{~S} / 1.72$ \\
\hline \multicolumn{5}{|c}{} \\
\end{tabular}

Finally, in Table 9 and

Table $\mathbf{1 0}$ the unit price analysis is presented both in the standard concrete and in the concrete with replacement of $5 \%$ RHA per $\mathrm{m}^{3}$ of concrete mix; the mixture with RHA being the cheapest per $\mathrm{m}^{3}$.

\section{Results analysis}

\subsection{Soundness of fine and coarse aggregates in Magnesium Sulfate}

In the work [20] he breakdown of the coarse aggregate of the Vista Hermosa quarry is analyzed using the $1 / 2$ ", $3 / 8$ " and No. 4 sieves. The results expressed in Figure 5 indicate different weight losses depending on the sieves, being for the $1 / 2$ "sieve of $0.67 \%, 3.64 \%$ for $3 / 8$ " and $11.63 \%$ for sieve No. 4. This behavior of weight loss increases as the sieve diameter decreases as it passes from $1 / 2$ "to $3 / 8$ " is similar to the one studied, differing in sieve No. 4 where the increase continues unlike the decrease that occurs for the quarry studied; resulting in a low quality material and high porosity. This is because the aggregate is not substantially reactive with the alkalis and the moisture is not enough for the alkalis to enter into solution, thus avoiding the alkali-aggregate reaction.

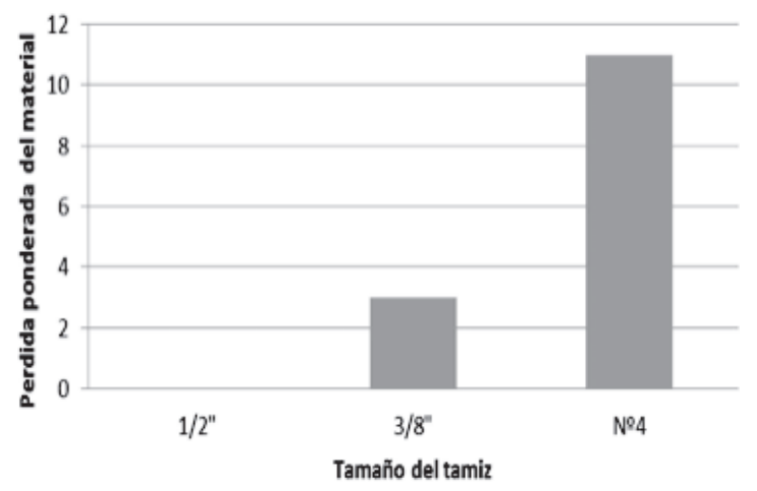

Figure 5. Weighted loss of quarry material Vista Hermosa (Mosquera).

On the other hand, the authors [8], study the disintegration of the fine aggregate inflicted in Sodium Sulfate and Magnesium Sulfate for sizes from 8 to $20 \mathrm{~mm}, 4$ to $10 \mathrm{~mm}$ and 0 to $4 \mathrm{~mm}$. They study two cases, that of diabasa or black granite and that of limestone; In both cases the percentage of weight loss increases as the particle size decreases. This trend is most noticeable when aggregates are inflicted by Magnesium Sulfate.

\subsection{Compressive strength}

The author [15], carries out a study with $20 \%, 30 \%$ and $40 \%$ ash from crushed rice bark (GRHBA), a Portland Type I Cement and Super Plasticizer Additive; their results indicate that GRHBA 20\% replacement concrete has a maximum compressive strength between $95 \%$ and $105 \%$ of the control concrete's resistance and that for $30 \%$ and $40 \%$, the resistance decreases to $98 \%$ of resistance of control concrete.

This behavior is similar to the one studied, in the case of the compressive strength growth the peak value is due to its high percentage of pozzolan that has the composition of rice husk ash, being more than $80 \%$ of silicon dioxide $\left(\mathrm{SiO}_{2}\right)$, highly pozzolanic material, present in the chemical composition of cement [21]. In the case of the decrease in resistance, this is because the high percentages of RHA fail to compensate for the loss of Clinker minerals generated by cement replacement [22], affecting the porosity and cellular structure of the particles [23].

It's worth mentioning other studies carried out by [14], who studies the incidence of $5 \%, 15 \%$ and $25 \%$ of RHA with an Ordinary Portland Cement (OPC) and obtains a decreasing behavior of compressive strength as the percentage increases of RHA, all its strengths being greater than those of the $20 \mathrm{MPa}$ design at 28 days, but none of them greater than the resistance of the control concrete. On the other hand, [15] with the replacement of $20 \%, 30 \%$ and $40 \%$ of GRHBA studies the resistance to compression at 7, 28 and 90 days of curing in cubic specimens of $10 \mathrm{~cm}$ side with superplasticizer additive finding that the Compressive strength at the age of 7 days of concrete with RHA is superior to conventional concrete, this behavior being due to the rapid reaction of the cement hydration mechanism.

\subsection{Rapid penetration by chloride ions}

The authors [15], using $20 \%, 30 \%$ and $40 \%$ of GRHBA, Portland Cement Type I, SP Additive and an a / c ratio of 0.46 , obtain a similar behavior; they mention that the penetration of chloride sized in Coulomb decreases as the replacement percentage increases and as it acquires more time in the hardened state. On the other hand, [24] study the incidence of RHA with different percentages $(15 \%$, $25 \%, 35 \%$ and $50 \%$ ), in the rapid penetration of chloride ions and use an a/c ratio of 0.45 and 0.65 , obtaining a decrease in the chloride diffusion coefficient as the percentage of cement replacement by RHA increases.

These trends are similar to those studied and their behavior is due to the increase in the amount of pozzolanic reaction and hydration. Likewise, the fine particles of the RHA could fill the voids generated by the porosity of the concrete and, also, the nucleation for the acceleration of the hydration in the cement paste [23]. 


\subsection{Water penetration depth under pressure}

The authors [25], using waste from an out-of-service rail structure, specifically particles with sizes between 0.01 $\mathrm{mm}$ and $10 \mathrm{~mm}$ of destroyed ballasts and sleepers demonstrated that, with these additions to concrete, the penetration depth decreases from $50 \mathrm{~mm}$ to $20 \mathrm{~mm}$ in maximum depth of water penetration under pressure.

Likewise, [26] study the relationship of durability indicators with water transport for a concrete with $20 \%$ replacement and $50 \%$ cement by thermally activated coal mining waste (ACMW) with particle sizes of $0.1 \mu \mathrm{m}$ at $100 \mu \mathrm{m}$. They concluded that although adding ACMW increased water permeability under pressure, these mortars could be considered waterproof in more aggressive environments.

These results resemble those of our study; adding fine particles to concrete could significantly increase its impermeability. This is because the permeability depends on factors such as the average pore size, the total porosity or the volume of macropores [27]. In our study, the penetration depth decreases as the percentage of RHA increases, the most favorable being the concrete sample with replacement of $15 \%$ RHA with a maximum penetration of $35 \mathrm{~mm}$.

\subsection{Cost evaluation}

In the indicated Table 9 and

Table 10 above, the price variation for the addition of RHA is approximately $\mathrm{S} / .8 .12$ ( $€ 2.12$ euros) which is $2.96 \%$ lower than the standard concrete, which means that the addition of 5\% RHA is a good alternative for the manufacture of concrete.

\section{Conclusions}

- The replacement of RHA in the concrete mix produces high resistance at early ages and to develop a waterproof concrete resistant to chloride ion penetration and water permeability.

- The disintegration of the aggregates against the magnesium sulfate solution presents an acceptable disintegration for the marine structures, reducing the impact of the absorption capacity on the part of the gel thus avoiding the presence of cracks. However, disintegration must be tested against sodium sulfate solutions for greater versatility in the interpretation of results.

- The compressive strength of concrete with 5\% RHA replacement surpasses the standard concrete at an early age due to the high pozzolanic activity of rice husk ash; However, after 28 days, a small decrease is observed with respect to the standard concrete, this can lead to an inconvenience in the excessive addition of water with respect to the mixture design.

- The rapid penetration by chloride ions in the concrete with rice husk ash replacement is lower compared to the standard concrete, which means less destruction in the passive layer of the steel reinforcements in the structure, due to the increase of the pozzolanic reaction and hydration presented by RHA.

- The increase in the addition of RHA produces a less water permeable concrete that contributes to a possible de-passivation of reinforcing steels in structures.

- The economic analysis of the concrete with 5\% RHA replacement with respect to the standard concrete has a lower cost per $\mathrm{m}^{3}$ so it can be concluded that the concrete with RHA replacement is a sustainable concrete since it decreases the use of cement in the mix.

- The replacement of cement in percentage of RHA and used in the mixing of the standard concrete allows to produce a sustainable concrete as an alternative to reduce agricultural waste.

\section{References}

1. G. Civilízate, "Emisiones de Carbono por parte de la industria del cemento vs cemento verde," $C I V$, pp. 12, 2006.

2. A. A. Zaid and O. Ganiyat, "Comparative utilization of biodegraded and undegraded rice husk in Clarias gariepinus diet," African Journal of Biotechnology, vol. 8, no. 7, pp. 1358-1362, 06 Abril 2009.

3. Y. Safa and H. Bhatti, "Adsorptive removal of direct dyes by low cost rice husk: Effect of treatments and modifications," African Journal of Biotechnology, vol. 10, no. 16, pp. 3128-3142, Mayo 2011.

4. B. Singh, "Rice husk ash," Waste and Supplementary Cementitious Materials in Concrete, pp. 417-460, 2018.

5. J. Smith, "Types of marine concrete structures," Marine Concrete Structures, pp. 17-64, 2016.

6. H. Baorong, L. Xiaogang and X. Ma, "The cost of corrosion in China," Materials Degradation, vol. 1, no. 4, 25 Julio 2017.

7. ACI Committee 221, "State of the Art Report on Alkali Aggregate Reactivity," American Concrete Institute, 1998.

8. I. Ioannou, R. Fournari and M. F. Petrou, "Testing the soundness of aggregates using different methodologies," Construction and Building Materials, vol. 40, pp. 60-610, 2013.

9. S. Abbas, "Potential of rice husk ash for mitigating the alkali-silica reaction in mortar bars incorporating reactive aggregates," Construction and Building Materials, vol. 132, no. 1, pp. 61-70, 2017.

10. J. Zuquan, Z. Xia, Z. Tiejun and L. Jianqing, "Chloride ions transportation behavior and binding capacity of concrete exposed to different marine corrosion zones," Construction and Building Materials, vol. 177, pp. 170-183, 2018.

11. L. Dawang, "Chloride diffusion model for concrete in marine environment with considering binding effect," Marine Structures, vol. 66, pp. 44-51, 2019.

12. K. D. O. Ravindra, "10 - Recycled Aggregate 
Concrete: Durability Properties," Sustainable Construction Materials, pp. 365-418, 2019.

13. K. Shicong and C. S. Poon, "Compressive strength, pore size distribution and chloride-ion penetration of recycled aggregate concrete incorporating class-F fly ash," Journal of Wuhan University of TechnologyMaterials, vol. 21, no. 4, pp. 130-136, 2006.

14. A. R. Mustaqqim, M. I. Norlia, I. Zulliza, G. Zuhayr Md, S. Shahiron, L. R. Nur, A. S. Liyana and N. F. Isa, "Properties Of Concrete With Different Percentange Of The Rice Husk Ash (RHA) As Partial Cement Replacement," Materials Science Forum, vol. 803, pp. 288-293, 2015.

15. R. Sumrerng and C. Prinya, "Use of Rice Husk-Bark Ash in Producing Self-Compacting Concrete," Hindawi Publishing Corporation, vol. 2014, p. 6, Enero 2014.

16. ACI Committee 211, "Guide for Selecting Proportions for No-Slump Concrete," American Concreto Institute, Estados Unidos, 2009.

17. ASTM International C88, Standard Test Method for Soundness of Aggregates by Use of Sodium Sulfate or Magnesium Sulfate or Magnesium Sulfate, West, 2018.

18. ASTM International C39, Método de Ensayo Normalizado para Resistencia a la Compresión de Especímenes Cilíndricos de Concreto., ASTM, 2018.

19. ASTM International C1202 - 12, Standard Test Method for Electrical Indication of Concrete's Ability to Resist Chloride Ion Penetration, 2018.

20. L. N. Tiusabá, N. Borda, A. Rivera and L. A. Moreno, "Solidez de los Agregados Pétreos Mediante la Adición de Sulfato de Magnesio," Ingeniería e Innovación, vol. 3, no. 2, 25 Julio 2015.

21. B. Reddy, "Effect of rice husk ash on the properties of ordinary portland cement and portland slag cement with and without superplasticiers," Trans
Stellar, pp. 1-8, 2013.

22. S. Antiohos, S. Tsimas and V. Papadakis, "Rice husk ash (RHA) effectiveness in cement and concrete as a function of reactive silica and fineness," Cement and Concrete Research, Vols. 61-62, pp. 20-27, Julio 2014.

23. R. Sumrerng and C. Prinya, "Utilization of bagasse ash in high-strength concrete," Materials \& Design, vol. 34, pp. 45-50, Febrero 2012.

24. T. S. P. S. y. C. J. W. Chalee, "Utilization of rice husk-bark ash to improve the corrosion resistance of concrete under 5-year exposure in a marine environment," Cement \& Concrete Composites, vol. 37, pp. 47-53, Marzo 2013.

25. J. Sainz-Aja, I. Carrascal, J. A. Polanco, C. Thomas, I. Sosa and J. Casado, "Self-compacting recycled aggregate concrete using out-of-service railway superstructure wastes," Journal of Cleaner Production, vol. 230, pp. 945-955, 01 September 2019.

26. L. Caneda-Martínez, C. Medina, M. I. Sánchez de Rojas and M. Frías, "Water transport in binary ecocements containing coal mining waste," Cement and Concrete Composites, vol. 104, p. 103373, Noviembre 2019.

27. C. Medina, M. I. Sánchez de Rojas and M. Frías, "Properties of recycled ceramic aggregate concretes: Water resistance," Cement and Concrete Composites, vol. 40, pp. 21-29, Julio 2013. 